Article

\title{
Creating Sustainable Meals Supported by the NAHGAST Online Tool-Approach and Effects on GHG Emissions and Use of Natural Resources
}

\author{
Melanie Speck ${ }^{1, *}$, Katrin Bienge ${ }^{1}$, Lynn Wagner ${ }^{1}$, Tobias Engelmann ${ }^{2}{ }^{\circledR}$, Sebastian Schuster ${ }^{1}$, \\ Petra Teitscheid ${ }^{2}$ and Nina Langen ${ }^{3}$ D \\ 1 Wuppertal Institute for Climate, Environment and Energy gGmbH, Döppersberg 19, 42103 Wuppertal, \\ Germany; katrin.bienge@wupperinst.org (K.B.); lynn.wagner@wupperinst.org (L.W.); \\ sebastian.schuster@wupperinst.org (S.S.) \\ 2 Institute of Sustainable Nutrition, University of Applied Science Münster, iSuN, Corrensstraße 25, \\ 48149 Münster, Germany; tobias.engelmann@fh-muenster.de (T.E.); petra.teitscheid@fh-muenster.de (P.T.) \\ 3 Institute of Vocational Education and Work Studies, Technische Universität Berlin, Marchstraße 23, \\ 10587 Berlin, Germany; nina.langen@tu-berlin.de \\ * Correspondence: melanie.speck@wupperinst.org
}

Received: 30 December 2019; Accepted: 3 February 2020; Published: 5 February 2020

\begin{abstract}
Every diet has an impact on an individual's health status, the environment, as well as on social concerns. A growing number of meals are consumed in the out-of-home catering sector, in which a systematic sustainability assessment is not part of common practice. In order to close this gap, an instrument was developed as part of the NAHGAST project. After more than one year of using the NAHGAST online tool, it needs to be assessed what positive environmental influences can be realized by using the tool. For this reason, this article deals with the question of whether an online tool can enable stakeholders from the out-of-home consumption sector to revise their meals with regard to aspects of a sustainable diet. In addition, it will be answered how precise recipe revisions of the most popular lunchtime meals influence the material footprint as well as the carbon footprint. In conclusion, an online tool can illustrate individual sustainability paths for stakeholders in the out-of-home consumption sector and enables an independent recipe revision for already existing meals. The results show that even slight changes in recipes could lead to savings of up to a third in carbon footprint as well as in material footprint. In relation to the out-of-home consumption sector, this results in the potential for substantial multiplication effects that will pave the way for the dissemination of sustainable nutrition.
\end{abstract}

Keywords: sustainable nutrition; sustainable diet; nutritional footprint; health; environment; out-of-home gastronomy

\section{Introduction}

A sustainable diet consists of four fundamental dimensions: nutrition, economics, society and environment [1]. Not only is it advisable to consider these dimensions simultaneously [2], it can also be advantageous as, by the current state of scientific knowledge, a resource-efficient diet is often a healthier one [3-8]. Meat-reduced diets [9-12] for example, have a lower environmental impact since plant-based diets hold an ecological reduction potential of about $20 \%-30 \%$ compared to an omnivore diet [13-15]. A substantially higher reduction can even be observed when looking at individual indicators (e.g., land use of up to $40 \%$ [16], $\mathrm{NH}_{3}$ emissions of up to $89 \%$ [17]). The less animal-based products are consumed, the higher the potential savings. Foods that contribute to a healthy diet, such as some vegetables or nuts [18] as well as some types of fruit, fish and seafood [19], may nevertheless also 
have a major environmental impact. The same may apply to highly processed plant-based substitutes for meat and dairy products $[7,20]$. Stakeholders in out-of-home catering, therefore, have to face the challenge of putting meals together in a way that takes all fundamental factors of a sustainable diet into account [21-24].

After food retailing, out-of-home catering is the second most important sales channel for the German food industry [25]. More and more people are making use of out-of-home consumption offers [25]. The sector is a highly relevant field of action with regard to the transformation towards sustainable nutrition, because of the high number of meals sold daily. In 2018, German out-of-home catering recorded around 11.8 million daily customers (excluding the health sector) with a market volume of around 80.6 billion euros [25]. Furthermore, the out-of-home sector is expected to proportionally increase to $40 \%$ of food sales in Germany over the next few years [26]. These prospects are supported by the fact that the number of meals consumed at home decreased by 3 billion between 2005 and 2015 [27]. The choice of lunch primarily depends on the time available as well as on the monetary budget. In addition, respondents also mentioned other reasons for their choice of meals [28-31]. The commonly named "food environment" [32]—describing the nearby gastronomical infrastructure-has a considerable influence on a person's lunch selection. Given the increasing importance of the sector, it becomes apparent that stakeholders need support in the composition of healthy, fair, affordable and ecologically sound meals in order to take advantage of the large multiplication effects this sector has to offer.

In order to use the potential of out-of-home consumption both in terms of reaching a large number of people and supporting them in changing their diets as well as offering assistance to out-of-home catering stakeholders in accounting procedures, an online assessment framework has been created. This practical instrument, which can be used by companies from the out-of-home sector to assess the sustainability of their offered menus, was developed as part of the NAHGAST I project. The online tool was launched in March 2018 and has been registering more than 1500 analyzed meals since that date. NAHGAST I (from March 2015 to February 2018) was a research project funded by the German Federal Ministry of Education and Research, which aimed at the initiation and dissemination of transformation processes for sustainable production and consumption in out-of-home gastronomy. In addition to the transdisciplinary research team, several practical partners from different areas of out-of-home catering (care, business, education) have been involved. In the subsequent project NAHGAST II (from June 2019 to November 2020), the developed communication concepts and concepts of transfer will be optimized in order to increase the use of the online tool and the accompanying NAHGAST manual of practice as well as to guarantee the connectivity to existing digital systems, such as recipe management or ERP (Enterprise Resource Planning). The implementation is supported by the close cooperation of 20 additional practical partners.

Within the NAHGAST project, numerous tests underline that guests might be more likely to choose a more sustainable meal if out-of-home catering stakeholders were supported in expanding their range of offers with resource-friendly and tasty menus [33,34]. Furthermore, the project clarifies that stakeholders within the out-of-home consumption sector can be supported in the improvement of existing offers in order to take advantage of the popularity of meals already accepted by customers. This is one example in which sustainable nutrition is not only defined as ecologically compatible, health-promoting and fair in cost, but also as culturally accepted [1,21,35]. In this case, it is an improvement that recipes can be revised from a health related and ecological point of view. With the help of the developed NAHGAST online tool, for example, the proportion of meat and meat-based products in recipes such as goulash or curry dishes could be reduced while the proportion of vegetables could be increased simultaneously. The idea of independent and appropriate recipe revisions of existing meals by stakeholders themselves, while using a science-based tool, led to the main intention of this article. Within the scope of the cooperation with the practical partners, it becomes clear that it is necessary to work within the existing structures to initiate changes. Therefore, the main aim is to point out what small changes can be achieved, especially in companies in the out-of-home catering sector 
where up to 2500 people are being served every day. Against this background, the following research questions arise:

- Does an online tool like the NAHGAST instrument enable stakeholders of out-of-home-catering to revise their meals with regard to aspects of a sustainable diet?

- How big are the ecological reduction potentials in the out-of-home consumption sector in terms of meal revision if the NAHGAST tool is used?

To answer these research questions, the dataset generated with the NAHGAST online tool has been analyzed. Based on user data, different types of diets were evaluated and several recipes were presented in detail. Finally, a scenario was used to identify the ecological benefits that can be achieved in the out-of-home consumption sector by using the NAHGAST online tool.

\section{Materials and Methods}

\subsection{Food Sustainability Assessment Using the NAHGAST Online Tool}

Tools help to evaluate meals in the out-of-home catering sector with regard to various sustainability aspects [36-42]. The instruments primarily refer to health related and ecological criteria. In some cases, they were customized to internal company structures and are, therefore, not accessible to all participants of the out-of-home consumption sector. To develop a comprehensible assessment method that allows stakeholders in the out-of-home catering sector to implement sustainability assessments themselves, a cost-free tool based on the Nutritional Footprint, was developed in the test phase of the NAHGAST project [13]. The methodology has been developed by considering the environmental, social, health and economic dimensions and by selecting indicators for each one of them to make them measurable. The indicators used for this purpose were selected in a stakeholder process according to their scientific relevance, their feasibility (also with regard to data availability) and their communicability [39]. Material footprint, carbon footprint, water use and land use were selected as indicators for the environmental dimension. According to the MIPS concept (Material Input Per Service unit), the material footprint is a measurement for the life cycle resource requirement of a meal and is stated in kilogram of resources $[43,44]$. It comprises the direct and indirect demand for abiotic (all mineral raw materials, including economically unused raw materials such as overburden or excavated soil) and biotic raw materials (mainly plant-based biomass from agriculture and forestry). The carbon footprint is the total amount of released greenhouse gases and is stated in kilograms of carbon dioxide equivalents that are caused directly and indirectly by an activity or are released over the different life stages of a product, according to the IPCC 2007 methodology [45]. The social dimension includes the indicators of share of fair ingredients as well as shares of animal-based food that foster animal welfare. Health indicators include energy, fat, carbohydrates, sugar, salt and fibers. Finally, the popularity and cost recovery of meals were chosen as indicators for the economic dimension.

Following this selection process, a sustainable level was defined for each indicator. Sustainable levels can be used to generate target values for each indicator to assess whether a meal contributes to achieving quantitative target values for sustainability. This boundary approach is derived from the idea of the planetary boundaries proposed by Röckstrom et al. [46,47]. The latter are defined partly on the basis of concrete scientific recommendations and partly on the basis of target values, whereby this applies in particular to environmental indicators. Table 1 summarizes all sustainable levels for a lunchtime meal: 
Table 1. Indicators and sustainable levels applied in the NAHGAST instrument.

\begin{tabular}{|c|c|c|c|c|}
\hline Dimension & Environment & Social & Health & Economic ${ }^{1}$ \\
\hline Indicator & $\begin{array}{c}\text { Material Footprint } \\
(<2670 \mathrm{~g} /<4000 \mathrm{~g}) \\
\text { Carbon Footprint } \\
(<800 \mathrm{~g} /<1200 \mathrm{~g}) \\
\text { Water use } \\
(<640 \mathrm{~L} /<975 \mathrm{~L}) \\
\text { Land use } \\
\left(<1.25 \mathrm{~m}^{2} /<1.875 \mathrm{~m}^{2}\right)\end{array}$ & $\begin{array}{c}\text { Share of fair } \\
\text { ingredients } \\
\quad(>90 \% />85 \%) \\
\text { Share of animal-based } \\
\text { food that foster animal } \\
\text { welfare }(>60 \% />55 \%)\end{array}$ & $\begin{array}{c}\text { Energy } \\
(<670 \mathrm{kcal} /<830 \mathrm{kcal}) \\
\text { Fat }(<24 \mathrm{~g} /<30 \mathrm{~g}) \\
\text { Carbohydrates }(<90 \\
\mathrm{g} /<95 \mathrm{~g}) \\
\text { Sugar }(<17 \mathrm{~g} /<19 \mathrm{~g}) \\
\text { Fibers }(<8 \mathrm{~g} />6 \mathrm{~g})\end{array}$ & $\begin{array}{c}\text { Popularity } \\
\text { (without quantified } \\
\text { target value) } \\
\text { Cost recovery } \\
\text { (without quantified } \\
\text { target value) }\end{array}$ \\
\hline
\end{tabular}

${ }^{1}$ The dimension economy was not included in the online tool and was therefore not further considered in this paper. The main reason was the availability of data. It was assumed that both cost recovery and a certain popularity of the dishes can be assumed in the catering facilities examined.

The "German Nutrition Society" (Deutsche Gesellschaft für Ernährung DGE) has set target values for the health sector, for example, the energy content of a lunchtime meal [48]. Environmental target values or sustainable levels only exist at a superior level, such as with regard to the total material input (in material footprint) per person and year with a maximum of eight tons [14], or 2-3 tons in the nutritional sector. Maximum and minimum levels per meal were defined for each indicator, e.g., by proportionally reducing the maximum resource input per year to a maximum level per day and then per lunchtime meal. This results in a maximum material consumption of $4000 \mathrm{~g}$. If a dish exceeds the level of more than $4000 \mathrm{~g}$, it is classified as unsustainable. If the dish achieves a result of less than $2670 \mathrm{~g}$, it meets the sustainable level and is declared as recommendable. The range in between defines a tolerance range in which the meal is declared as limited recommendable. For the social dimension, a solution was developed in close exchange with the five practical partners from different sectors (education and care catering, event catering), and a stakeholder workshop was held in order to reflect social implications through widespread labels or certificates (e.g., the Fair Trade Label) (This solution is to be critically reflected and possibly revised within the scope of the current NAHGAST II project). As the subsequent project NAHGAST II shows, the results from the NAHGAST I project can be classified as comprehensive and mostly representative. Many organizations can work with it. A further feedback process with practitioners (from similar and other out-of-home areas) can identify further improvements, e.g., the missing login area or the currently unchangeable portion size.

The sustainable levels are numerically encoded to form an index with regard to the level of dimension and to provide comparability between the single indicators. At the indicator level, the assessment takes place on a three-step scale: recommendable $=3$, limited recommendable $=2$, not recommendable $=1$. At the dimension level, a more differentiated assessment takes place on a six-step scale. In order to convert the values of the three-step scale resulting from the indicators into a six-step scale, the arithmetic mean of the indicators $(x I n d)$ of one dimension $(x \mathrm{Dim})$ is first calculated. Afterwards it is transformed up to the 6 th scale (by the term $x I n d-1 \times 1.5$ ). This results in the following calculation:

$$
x_{\text {Dim }}=\bar{x}_{\text {Ind }}+\left(\bar{x}_{\text {Ind }}-1\right) \times 1.5
$$

\subsection{Evaluation of User Data}

\subsubsection{Average Dimension and Indicator Results}

To be able to compare the results of different types of diets at level of dimensions (according to the dimensions of environment, social and health) health indicators (energy, fat, carbohydrates, fibers, sugar and salt) and environmental indicators (material footprint, carbon footprint) a statistical analysis of the user data is necessary. In this paper, the focus was on the analysis of the environmental indicator's material footprint and carbon footprint in relation to the assessed recipes. The average results of the indicators' land use and water use were therefore not shown for reasons of clarity. For this purpose, all data collected up to this point $(n=1509$; status 8 August 2019) were analyzed using the 
statistical software " $\mathrm{R}$ ". Incomplete data series were excluded. A distinction was made between vegan, vegetarian and mixed diets (meat and fish dishes).

In order to ensure that the recipes added by the users can be clearly assigned to a certain type of diet, an additional variable was created within the data set, which specifies the value of the sum of all ingredients contained in the recipe. Each ingredient is clearly assigned whether it contains vegan $(=0)$, vegetarian $(=1)$ or meat/fish $(=100)$ components. If the sum of all recipe ingredients is 0 , the recipe is assigned the value "vegan". If the sum of all ingredients is $>0$ and $\leq 99$, the recipe is classified as "vegetarian". If the sum of all ingredients is $>100$, the recipe is assigned to the value of a mixed diet.

To calculate the average result, the arithmetic means of all scores at dimension level as well as the environmental and health indicators were determined separately for each type of diet.

\subsubsection{Determination of the Environmental Impact of Recipe Modifications}

In order to measure the environmental impact caused by the tools, the ten recipes most frequently analyzed and revised by the users had to be identified and assessed in terms of absolute and relative savings respective to material footprint and carbon footprint. For this purpose, the virtual recipe revision was analyzed on the basis of the so far existing user data $(n=1509$; status 8 August 2019). Although the recipe revisions were conducted on a virtual level, they were implemented comprehensively by practical partners in the course of the NAHGAST I project and over the project's course of time.

As only direct comparisons between original recipes and revised recipes are to be taken into account, initially all data records relating to recipes that were only assessed once and that were not subsequently optimized were excluded. The remaining data were analyzed using a frequency count. For this purpose, the data set has been transferred to the spreadsheet software Microsoft Excel and the frequency count was carried out manually as the titles and spellings of the same recipes could vary. Comparable recipes (e.g., sausage with potato salad and sausage with baked potatoes) were grouped into one meal category. For the ten most frequently optimized meals, all recipe modifications made by users were collected, e.g., the substitution or partial reduction of individual ingredients.

Next, it was quantified which impacts on the two indicators of material footprint and carbon footprint could be implemented through these recipe modifications. For this purpose, a standard recipe was selected from the data as a reference for each of the ten meals. Previously collected modifications regarding ingredients or quantities were added to these reference recipes. Partial changes in ingredients were given as a percentage in order to avoid transfer mistakes due to different portion sizes from the original recipe. Eventually, an assessment of the material footprint as well as carbon footprint was made and put in relation to the results of the reference meal for each modified recipe. An exemplary calculation for a fictitious recipe is given in Table 2. The first column shows the ingredients of a standard recipe that has not been revised with the help of the tool as well as the corresponding results of the material footprint and carbon footprint. Columns two and three each contain two revised recipes. To identify recipe optimizations, all ingredients of the revised recipes were compared with the reference recipe. In the revised recipe 1, milk was partly $(66 \%)$ replaced by soy drink. In the revised recipe 2, rapeseed oil was used instead of butter. To be able to identify the impact of each recipe change on the indicators individually, it was applied to the reference system in a separate manner and the material footprint and carbon footprint were calculated again. 
Table 2. Exemplary calculation: Pancake recipe revisions.

\begin{tabular}{|c|c|c|c|c|c|c|}
\hline & \multicolumn{2}{|c|}{ Reference Recipe } & \multicolumn{2}{|c|}{ Revised Recipe 1} & \multicolumn{2}{|c|}{ Revised Recipe 2} \\
\hline & \multicolumn{2}{|c|}{ Conventional Pancakes } & \multicolumn{2}{|c|}{$\begin{array}{l}\text { Partial ( } 66 \%) \text { Substitution } \\
\text { of Milk by Soy Drink }\end{array}$} & \multicolumn{2}{|c|}{$\begin{array}{c}\text { Substitution of Egg by } \\
\text { Banana }\end{array}$} \\
\hline & $75 \mathrm{~g}$ & Wheat flour & $75 \mathrm{~g}$ & Wheat flour & $75 \mathrm{~g}$ & Wheat flour \\
\hline & $75 \mathrm{~g}$ & milk & $25 \mathrm{~g}$ & milk & $75 \mathrm{~g}$ & milk \\
\hline & & & $50 \mathrm{~g}$ & soy drink & & \\
\hline & $1 \mathrm{pc}$ & egg & $1 \mathrm{pc}$ & egg & $1 \mathrm{pc}$ & egg \\
\hline & $1 \mathrm{~g}$ & salt & $1 \mathrm{~g}$ & salt & $1 \mathrm{~g}$ & salt \\
\hline & $10 \mathrm{~g}$ & butter & $10 \mathrm{~g}$ & butter & $10 \mathrm{~g}$ & Rapeseed oil \\
\hline & $3 \mathrm{~g}$ & Baking powder & $3 \mathrm{~g}$ & Baking powder & $3 \mathrm{~g}$ & Baking powder \\
\hline & $10 \mathrm{~g}$ & sugar & $10 \mathrm{~g}$ & sugar & $10 \mathrm{~g}$ & sugar \\
\hline $\begin{array}{l}\text { Carbon footprint in } \mathrm{g} \\
\mathrm{CO}_{2} / \text { serving }(\%)\end{array}$ & \multirow{2}{*}{\multicolumn{2}{|c|}{682}} & \multicolumn{2}{|r|}{614} & \multicolumn{2}{|r|}{620} \\
\hline Savings & & & \multicolumn{2}{|r|}{$68(10.0)$} & \multicolumn{2}{|r|}{$62(9.1)$} \\
\hline $\begin{array}{l}\text { Material footprint in } \mathrm{kg} \\
\text { resources/ } \mathrm{kg}(\%)\end{array}$ & \multirow{2}{*}{\multicolumn{2}{|c|}{1634}} & & 1340 & \multicolumn{2}{|r|}{1347} \\
\hline Savings & & & \multicolumn{2}{|r|}{$294(18.0)$} & \multicolumn{2}{|r|}{$287(17.6)$} \\
\hline
\end{tabular}

\section{Results}

\subsection{Average Scores of Sustainability Assessment of User Recipes}

Since the online tool was launched, around 1509 meals have been created and evaluated using the instrument (status 8 August 2019). Slightly more than half of the meals consist of vegetarian or vegan dishes, which are divided equally between both diets. The remaining meals are meat or fish dishes.

When comparing the average scores of the three types of diets, it becomes clear that vegan meals perform best regarding all three dimensions, followed by vegetarian meals (Figure 1a). In general, it becomes clear that the fewer animal products a meal contains, the better the average score of all three dimensions. The environmental (Figure 1b) and health indicators (Figure 1c) illustrate the underlying assessment at indicator level. A comparison of the environmental indicators of carbon footprint (1.7-2.5) and material footprint (1.4-2.2), shows clear differences between the types of diets. Vegan meals clearly perform best, followed by vegetarian meals. Mixed diets show the lowest average results. The health indicators of carbohydrates (2.6-2.8), dietary fibers (2.2-2.4), energy (2.5-2.7) and sugar (2.6-2.7) score very similarly in all of the considered menu categories. The indicators fat (2.2-2.5) and salt (1.6-2.2) show major differences. Again, vegan or vegetarian meals generally perform better with regard to these indicators.

\subsection{Recipe Composition between Sustainability and Customer Acceptance}

An analysis of the user data revealed which meals were most frequently virtually assessed and subsequently improved. In addition, it was analyzed which specific recipe revisions were tested by users and which savings in material footprint and carbon footprint could be achieved, if the optimized recipes were implemented in practice. As already explained, several recipe revisions conducted virtually by using the NAHGAST tool have already been tested in practical implementation. Table 3 shows that the instrument was primarily used to revise meat-based meals, which, as described in the previous section, had a lower average score. Two main strategies were applied to the precise recipe modifications: on one hand, climate-intensive ingredients were partly reduced or avoided without a substitution. On the other hand, climate-intensive products were partly or completely substituted by more climate-friendly products. The aim is to maintain the characteristic properties of the meal, despite a change in the recipe, as much as possible in order to keep customer acceptance equally high and to only slightly change kitchen processes and routines. 


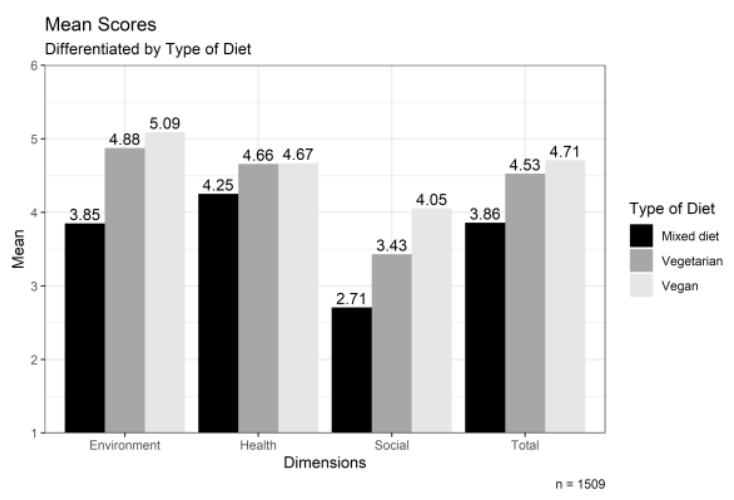

(a)

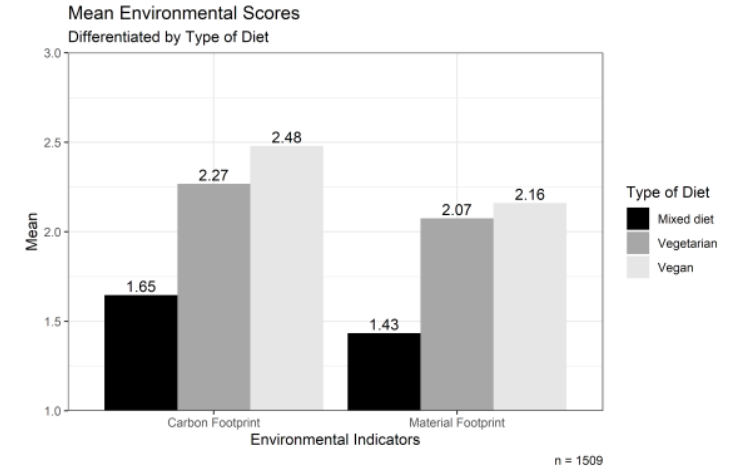

(b)

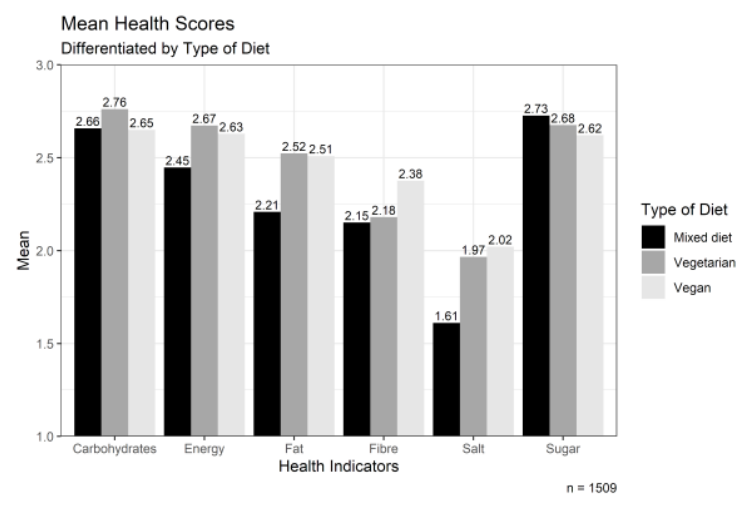

(c)

Figure 1. (a) Average total scores by diets; (b) Average environmental scores by diets; (c) Average health scores by diets (source: own work).

Table 3 lists the specific effects of the recipe modifications tested by the users. When looking at the savings in relation to carbon footprint and material footprint, it becomes clear that the reduction or substitution of meat, especially beef, is associated with the highest savings. If beef is (partly) substituted by a vegetable component, legumes or another type of meat, up to $37 \%$ of carbon dioxide equivalents can be saved depending on the type of dish. The partial reduction of the meat component without substitution allows savings of up to $30 \%$ of carbon dioxide equivalents. However, even the replacement of dairy products such as butter, cream or milk with plant-based products can lead to savings of up to $7 \%$. Similar results can be found when comparing the material footprint. Here too, savings of up to $34 \%$ can be achieved by replacing beef with less climate-sensitive ingredients.

The results show that recipe revisions conducted by users of the NAHGAST tool can lead to major improvements of the environmental indicators of material footprint and carbon footprint. It was demonstrated that even slight modifications, such as the substitution of a single ingredient, can improve the material footprint and carbon footprint of a meal by up to a third. 
Table 3. Changes in carbon footprint and material footprint of the ten most frequently optimized meals using the NAHGAST tool (sorted by descending popularity).

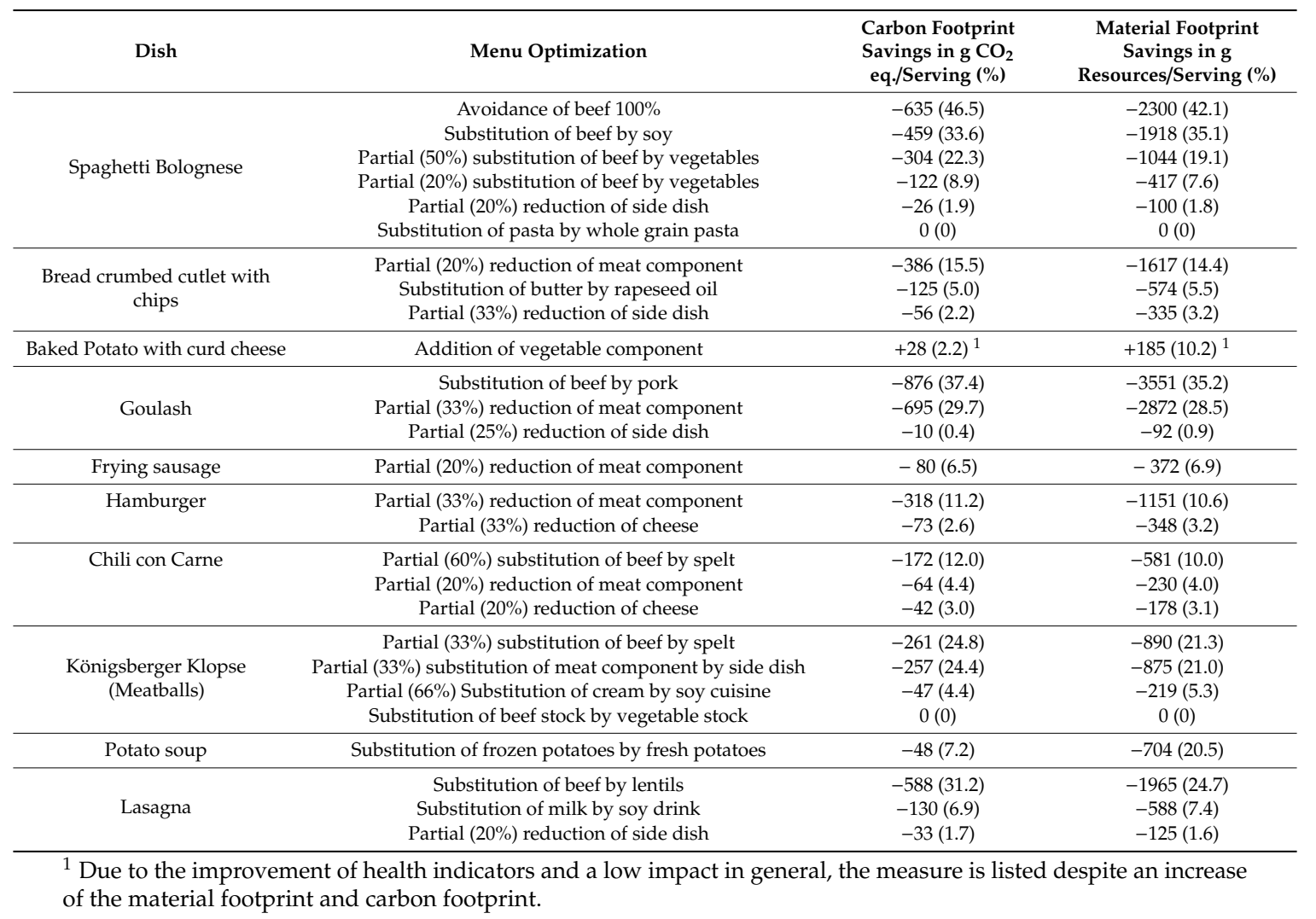

\subsection{Environmental Improvements in the Out-of-Home Catering Sector Using the NAHGAST Online Tool}

The current project illustrates which environmental impacts can be affected at the recipe level by using the NAHGAST tool. The second aim is to assess the environmental impacts caused by an instrument-based recipe revision in relation to the out-of-home consumption sector. The out-of-home gastronomy offers great multiplication effects and has, with 11.8 million daily customers [25], a large leverage effect for the transformation towards a sustainable nutrition. The NAHGAST tool has a high potential for dissemination in this sector due to its intuitive handling, low-threshold and cost-free access. Against this background, a scenario analysis was conducted that implies an extrapolation of absolute savings in material footprint and carbon footprint that could be achieved, if a nationwide caterer with 20 sites in Germany revised its recipes for lunchtime catering with the NAHGAST tool and implemented them into practice.

In order to assess the absolute savings in resources, a fictitious lunchtime meal plan has been composed. This plan includes one offered main course per working day. The menu was composed to be as practical as possible by combining five frequently offered meals that have been identified in Table 3 , being a meat-based menu with one vegetarian meal per week. A fictitious caterer with 20 nationwide sites and 300,000 servings per day was used as a reference, which corresponds to 1,500,000 servings per week referring to five working days. The number of servings was derived from the servings sold daily by the NAHGAST II practical partners.

Assuming that the nationwide caterer produced 300,000 servings per working day according to standard recipes, almost 3 million tons of $\mathrm{CO}_{2}$ equivalents would be produced per week (Table 4). Regarding the material footprint, more than 12 million tons of resources would be needed in order to produce 1,500,000 weekly servings in total (Table 5). If the menu would not be changed but every meal would be cooked according to a revised recipe, both material footprint and carbon footprint could be reduced considerably. Recipe revision involves various strategies. In the preparation of spaghetti 
Bolognese, the beef is replaced by granulated soy. In the preparation of hamburger and meatballs, the meat component is reduced in quantity. In the goulash dish, beef is replaced by pork. Finally, fresh potatoes are used instead of frozen potatoes for the preparation of the potato soup. The revised menu now contains two vegetarian meals and three meat-based meals. All recipe revisions taken together can result in savings of more than 0.6 million tons of $\mathrm{CO}_{2}$ equivalents (Table 4 ) and savings in material footprint of almost 2.7 million tons of resources per week (Table 5).

Table 4. Carbon footprint of five selected reference recipes and the corresponding optimized recipes per 300,000 servings.

\begin{tabular}{|c|c|c|c|c|c|}
\hline Standard Recipe & $\begin{array}{c}\text { Carbon Footprint } \\
\text { in kg CO2 } \\
\text { eq/Serving }\end{array}$ & $\begin{array}{l}\text { Carbon Footprint } \\
\text { in } \mathrm{t} \mathrm{CO} 2 \mathrm{eq} / \mathrm{d}\end{array}$ & $\begin{array}{l}\text { Revised Recipe (by the } \\
\text { NAHGAST Tool) }\end{array}$ & $\begin{array}{l}\text { Carbon Footprint } \\
\text { in kg CO2 } \\
\text { eq/Serving }\end{array}$ & $\begin{array}{l}\text { Carbon } \\
\text { Footprint in } t \\
\text { CO2 eq/d }\end{array}$ \\
\hline $\begin{array}{l}\text { Monday: Spaghetti } \\
\text { Bolognese }\end{array}$ & 1366 & 406,800 & Substitution of beef by soy $\left(\mathrm{V}^{1}\right)$ & 907 & 272,100 \\
\hline $\begin{array}{l}\text { Tuesday: Bread crumbed } \\
\text { cutlet with chips }\end{array}$ & 2490 & 747,000 & $\begin{array}{c}\text { Reduction of meat component } \\
\text { by } 20 \%\end{array}$ & 2104 & 631,200 \\
\hline Wednesday: Goulash & 2342 & 702,600 & Substitution of beef by pork & 1466 & 439,800 \\
\hline Friday: Potato soup (V) & 667 & 200,100 & $\begin{array}{l}\text { Substitution of frozen potatoes by } \\
\text { fresh potatoes }(\mathrm{V})\end{array}$ & 619 & 185,700 \\
\hline $\begin{array}{l}\text { Total carbon footprint } \\
\text { per week }\end{array}$ & & $\begin{array}{c}2,908,500 \\
\text { (according to } \\
\text { standard recipes) }\end{array}$ & & & $\begin{array}{c}2,285,400 \\
\text { (according to } \\
\text { revised recipes) }\end{array}$ \\
\hline
\end{tabular}

Table 5. Material Footprint of five selected standard recipes and the corresponding optimized recipes per 300,000 servings.

\begin{tabular}{|c|c|c|c|c|c|}
\hline Standard Recipe & $\begin{array}{l}\text { Material Footprint } \\
\text { in kg } \\
\text { Resources/Serving }\end{array}$ & $\begin{array}{l}\text { Material Footprint } \\
\text { in } t \text { Resources/d }\end{array}$ & $\begin{array}{l}\text { Revised Recipe (by the } \\
\text { NAHGAST Tool) }\end{array}$ & $\begin{array}{l}\text { Material Footprint } \\
\text { in kg } \\
\text { Resources/Serving }\end{array}$ & $\begin{array}{c}\text { Material } \\
\text { Footprint in } t \\
\text { Resources/d }\end{array}$ \\
\hline $\begin{array}{l}\text { Monday: Spaghetti } \\
\text { Bolognese }\end{array}$ & 5467 & 1640,100 & Substitution of beef by soy $\left(\mathrm{V}^{1}\right)$ & 3549 & $1,064,700$ \\
\hline $\begin{array}{l}\text { Tuesday: Bread crumbed } \\
\text { cutlet with chips }\end{array}$ & 10,471 & $3,141,300$ & $\begin{array}{l}\text { Reduction of meat component } \\
\text { by } 20 \%\end{array}$ & 8854 & $2,656,200$ \\
\hline Wednesday: Beef goulash & 10,089 & $3,026,700$ & Substitution of beef by pork & 6539 & $1,961,700$ \\
\hline Thursday: Hamburger & 10,834 & $3,250,200$ & $\begin{array}{c}\text { Reduction of meat component by } \\
\text { a third }\end{array}$ & 9684 & $2,905,200$ \\
\hline Friday: Potato soup (V) & 3434 & $1,030,200$ & $\begin{array}{l}\text { Substitution of frozen potatoes by } \\
\text { fresh potatoes }(\mathrm{V})\end{array}$ & 2730 & 819,000 \\
\hline $\begin{array}{l}\text { Material Footprint } \\
\text { per week }^{2}\end{array}$ & & $\begin{array}{c}12,088,500 \\
\text { (according to } \\
\text { standard recipe) }\end{array}$ & & & $\begin{array}{c}9,406,800 \\
\text { (according to } \\
\text { revised recipe) }\end{array}$ \\
\hline
\end{tabular}

This scenario illustrates that a comprehensive implementation of slight modifications of recipes using tool-based recipe revision in the out-of-home consumption sector could realize high resource savings overall. A large nationwide caterer could reduce its carbon footprint and material footprint by about one fifth per week by such a revision. Due to the high number of servings in this sector, small changes at recipe level can have a substantial environmental impact.

\section{Discussion}

This article aims to determine whether an online tool like the NAHGAST instrument enables out-of-home catering stakeholders to revise their meals with regard to aspects of a sustainable diet and wants to illustrate ecological reduction potentials. The results of 18 months of online sustainability assessment with the NAHGAST tool illustrate that the tool enables the identification of sustainability paths in an accessible way. It reliably indicates when recipes are classified as resource-intensive and less sustainable, and allows a virtual recipe revision by stakeholders of the out-of-home catering sector themselves. At this point, it cannot be definitively proven whether users are encouraged to implement 
a revision of their own recipes in their daily routine. This requires further research into which meals have been revised in practice, in what way and how often they are eventually offered.

Nevertheless, the results demonstrate that even small revisions of the recipes have a positive impact on the environmental indicators of material footprint and carbon footprint. The analysis of the indicators showed that especially the reduction of animal-based products led to an improvement. Meier, Christen and Masset et al. presented similar results $[5,17]$. In particular, the substitution or the partial reduction of meat components by vegetables or legumes led to the greatest environmental savings. This result coincides with the fact that a plant-based diet has a reduction potential of 20\%-30\% compared to omnivore diets [13-15]. With virtual optimization using the NAHGAST tool, even higher savings could be realized in places. In the case of spaghetti Bolognese, the substitution of beef by soy reduces the carbon footprint by up to $34 \%$ and the material footprint by up to $35 \%$. Reducing the meat component by one third and increasing the side dish by the same amount in the recipe for meatballs led to savings of $24 \%$ regarding the carbon footprint and $21 \%$ in the case of the material footprint. The scenario analysis illustrates an extrapolation of the absolute savings in case of the material footprint and the carbon footprint, and has substantiated the great leverage effect that exists in the out-of-home consumption sector. The tool can push this lever and increases the leverage effect by its dissemination. To enable dissemination, the tool is free of costs and therefore accessible to all out-of-home consumption stakeholders, including small and medium-sized companies. The dissemination potential could increase by integrating assessment criteria into the ERP (Enterprise Resource Planning) systems of kitchens.

The paper and its results are based on many years of transdisciplinary work with substantial participation of the practical partners. This includes, amongst others, practical help with recipe changes and product development, which was made possible by valid data and substantial results of the instrument and resulted in recognizable, comprehensible, reliable and measurable effects. Nevertheless, not all of the virtually optimized meals could be tested in practical implementation at the present time. This step has been approached in cooperation with the practical partners in the NAHGAST I project. A continuous evaluation of tested recipes is planned in the future. Within that context, the main aim is to evaluate the feasibility of meal revisions in out-of-home catering. On one hand, this includes whether the recipe revisions can be successfully integrated into established kitchen processes. On the other hand, it will be examined how the changes affect customer acceptance. In addition, the relationship between recipe revision and nutrient composition has not yet been considered specifically. For example, it is important to examine whether there is an equivalent substitution of climate-intensive products with more climate-friendly alternatives (As part of the project design, revised recipes were offered in specific test weeks. The regularity of changed recipes within the weekly menu is currently being evaluated as part of the NAHGAST II project).

The study is characterized by a high relevance for everyday life and by an intensive cooperation and substantial participation by the practical partners. Nevertheless, it must be noted that no comparison with practical partners from outside the project has been carried out so far. This also applies to the use of the tool itself, for example, the way users deal with unavailable data. There may be differences between users who edit the same recipe but choose different solutions for missing information or missing ingredients. Furthermore, it might also affect the practical implementation, for example, the feasibility of optimized meals. Such a comparison could provide additional information on data validity and could be used to continuously improve the tool. This gap will be addressed in future studies.

Finally, the information generated by the NAHGAST tool can not only be used by stakeholders in out-of-home catering to revise their offers with regard to aspects of a sustainable diet. Customers, in general, can also expand their knowledge by consuming sustainable meals in the out-of-home gastronomy and act as multipliers in private or occupational contexts. Furthermore, the instrument can be used by customers to revise meals in private households. In addition, food companies could use the sustainability index as a benchmark for their product development and their recipes. Nevertheless, 
the focus should continuously be on stakeholders within the out-of-home consumption sector in order to improve the tool with regard to their specific needs and to use the sector's leverage.

\section{Conclusions}

An online tool for the sustainability assessment of menus can illustrate individual sustainability pathways for actors in the out-of-home catering sector and enable them to improve their own menu with regard to a sustainable diet. This includes the optimization of existing recipes as well as the development of new sustainable dishes. Great ecological savings-nearly a third of GHG emissions, respectively, material inputs-could be realized.

These outcomes are relevant for the out-of-home sector in particular. Every day, 11.8 million customers in Germany make use of out-of-home gastronomy offers, this number being expected to even increase in the future, resulting in a large multiplication effect. A tool that is accessible to everyone opens up considerable potentials in this sector to contribute to the dissemination of a sustainable diet.

Author Contributions: Conceptualization, M.S., K.B. and L.W.; methodology, M.S., K.B. and L.W.; software, S.S.; validation, M.S., N.L. and P.T.; formal analysis, M.S. and L.W.; investigation, M.S. and L.W.; data curation, S.S.; writing —original draft preparation, M.S. and L.W.; writing-review and editing, K.B. and T.E.; visualization, S.S.; supervision, M.S., N.L. and P.T. All authors have read and agreed to the published version of the manuscript.

Funding: This research was funded by the Federal Ministry of Education and Research, reference number 01 UT1409.

Acknowledgments: We acknowledge financial support by Wuppertal Institute for Climate, Environment and Energy within the funding programme 'Open Access Publishing'.

Conflicts of Interest: The authors declare no conflict of interest.

\section{References}

1. Food and Agriculture Organization of the United Nations. International Scientific Symposium Biodiversity and Sustainable Diets United Against Hunger. Available online: http://www.fao.org/ag/humannutrition/28 506-0efe4aed57af34e2dbb8dc578d465df8b.pdf (accessed on 21 December 2019).

2. Willett, W.; Rockström, J.; Loken, B.; Springmann, M.; Lang, T.; Vermeulen, S.; Garnett, T.; Tilman, D.; DeClerck, F.; Wood, A.; et al. Food in the Anthropocene: The EAT-Lancet Commission on healthy diets from sustainable food systems. Lancet 2019, 393, 447-492. [CrossRef]

3. Tilman, D.; Clark, M. Global diets link environmental sustainability and human health. Nature 2014, 515, 518-522. [CrossRef] [PubMed]

4. Speck, M.; Bienge, K.; Engelmann, T.; Langen, N.; Teitscheid, P.; El Mourabit, X. Ressourcenleichten Konsum gestalten-die Stellschrauben der Außer Haus Gastronomie. Haushalt in Bildung und Forschung 2018, 3, 89-99.

5. Masset, G.; Soler, L.G.; Vieux, F.; Darmon, N. Identifying Sustainable Foods: The Relationship between Environmental Impact, Nutritional Quality, and Prices of Foods Representative of the French Diet. J. Acad. Nutr. Diet. 2014, 114, 862-869. [CrossRef]

6. GBD 2017 Diet Collaborators. Health effects of dietary risks in 195 countries, 1990-2017: A systematic analysis for the Global Burden of Disease Study 2017. Lancet 2019, 393, 1958-1972. [CrossRef]

7. Chai, B.C.; van der Voort, J.R.; Grofelnik, K.; Eliasdottir, H.G.; Klöss, I.; Perez-Cueto, F.J. Which Diet Hast he Least Environmental Impact on Our Planet? A Systematic Review of Vegan, Vegetarian and Omnivorous Diets. Sustainability 2019, 11, 4110. [CrossRef]

8. US Department of Agriculture. Scientific Report of the 2015 Dietary Guidelines Advisory Committee. 2015. Available online: https://health.gov/dietaryguidelines/2015-scientific-report/PDFs/Scientific-Report-of-the-2 015-dietary-guidelines-advisory-committee.pdf (accessed on 21 December 2019).

9. Marlow, H.J.; Hayes, W.K.; Soret, S.; Carter, R.L.; Schwab, E.R.; Sabate, J. Diet and the environment: Does what you eat matter? Am. J. Clin. Nutr. 2009, 89, 1699S-1703S. [CrossRef]

10. Mithril, C.; Dragsted, L.O.; Meyer, C. Dietary composition and nutrient content of the New Nordic Diet. Public Health Nutr. 2012, 16, 777-785. [CrossRef]

11. Dermini, S.; Berry, E.M. Mediterranean Diet: From a Healthy Diet to a Sustainable Dietary Pattern. Frontiers in Nutrition 2015. Available online: https://www.frontiersin.org/articles/10.3389/fnut.2015.00015/full (accessed on 21 December 2019). 
12. Van Dooren, C.; Marinussen, M.; Blonk, H.; Aiking, H.; Vellinga, P. Exploring dietary guidelines based on ecological and nutritional values: A comparison of six dietary patterns. Food Policy 2014, 44, 36-46. [CrossRef]

13. Lukas, M.; Rohn, H.; Lettenmeier, M.; Liedtke, C.; Wiesen, K. The nutritional footprint-Integrated methodology using environmental and health indicators to indicate potential for absolute reduction of natural resource use in the field of food and nutrition. J. Clean. Prod. 2016, 132, 161-170. [CrossRef]

14. Lettenmeier, M.; Liedtke, C.; Rohn, H. Eight Tons of Material Footprint-Suggestion for a Resource Cap for Household Consumption in Finland. Resources 2014, 3, 488-515. [CrossRef]

15. Cordts, A.; Spiller, A.; Nitzko, S.; Grethe, H.; Duman, N. Imageprobleme beeinflussen den Konsum. Von unbekümmerten Fleischessern, Flexitariern und (Lebensabschnitts-) Vegetariern. Fleischwirtschaft 2015, 7, 59-63.

16. Hallström, E.; Carlsson-Kanyama, A.; Börjesson, P. Environmental impact of dietary change: A systematic review. J. Clean. Prod. 2015, 91, 1-11. [CrossRef]

17. Meier, T.; Christen, O. Environmental Impacts of Dietary Recommendations and Dietary Styles: Germany as an Example. Environ. Sci. Technol. 2012, 47, 877-888. [CrossRef]

18. Vieux, F.; Soler, L.G.; Touazi, D.; Darmon, N. High nutritional quality is not associated with low greenhouse gas emissions in self-selected diets of French adults. Am. J. Clin. Nutr. 2013, 97, 569-583. [CrossRef]

19. Tom, M.S.; Fischebeck, P.S.; Hendrickson, C.T. Energy use, blue water footprint, and greenhouse gas emissions for current food consumption patterns and dietary recommendations in the US. Environ. Syst. Decis. (Former Environ.) 2016, 36, 92-103. [CrossRef]

20. Sabaté, J.; Soret, S. Sustainability of plant-based diets: Back to the future. Am. J. Clin. Nutr. 2014, 100 (Suppl. 1), 476S-482S. [CrossRef]

21. Drewnowski, A. Measures and metrics of sustainable diets with a focus on milk, yogurt, and dairy products. Nutr. Rev. 2017, 76, 21-28. [CrossRef]

22. Auestad, N.; Fulgoni, V.L. What Current Literature Tells Us about Sustainable Diets: Emerging Research Linking Dietary Patterns, Environmental Sustainability, and Economics. Am. Soc. Nutr. 2015, 6, 19-36. [CrossRef]

23. Jones, A.D.; Hoey, L.; Blesh, J.; Miller, L.; Green, A.; Shapiro, L.F. A Systematic Review of the Measurement of Sustainable Diets. Am. Soc. Nutr. 2016, 7, 641-664. [CrossRef]

24. Meybeck, A.; Gitz, V. Sustainable diets within sustainable food systems. Proc. Nutr. Soc. 2017, 76, 1-11. [CrossRef] [PubMed]

25. Bundesvereinigung der Deutschen Ernährungsindustrie. Jahresbericht 2018/2019. Available online: https://www.bve-online.de/presse/infothek/publikationen-jahresbericht/bve-jahresbericht-ernaeh rungsindustrie-2019 (accessed on 21 December 2019).

26. Rückert-John, J. Zukunftsfähigkeit der Ernährung. In Nachhaltigkeit und Ernährung. Production-Handel-Konsum; Brunner, K.M., Schönberger, G.U., Eds.; Campus Verlag, Frankfurt: New York, NY, USA, 2005; pp. $240-262$.

27. Göbel, C.; Scheiper, M.; Teitscheid, P.; Müller, V.; Friedrich, S.; Engelmann, T.; Neundorf, D.; Speck, M.; Rohn, H.; Langen, N.; et al. Nachhaltig Wirtschaften in der Außer-Haus-Gastronomie. Status-Quo-Analyse-Struktur und Wirtschaftliche Bedeutung, Nachhaltigkeitskommunikation, Trends. NAHGAST Arbeitspapier 1. Available online: https://www.nahgast.de/wp-content/uploads/2017/09/NAHG AST_APap1_Au\{ $\backslash$ T1 $\backslash$ ss\}er_Haus-Gastronomie.pdf (accessed on 21 December 19).

28. Speck, M.; Liedtke, C. Chancen und Grenzen nachhaltigen Konsums in einer ressourcenleichten Gesellschaft. In Jahrbuch Nachhaltige Ökonomie 2016/2017: Im Brennpunkt:Ressourcen-Wende; Rogall, H., Binswanger, H.C., Ekart, F., Grothe, A., Hasenclever, W.-D., Hauchler, I., Jänicke, M., Kollmann, K., Michaelis, N.V., Nutzinger, H.G., et al., Eds.; Metropolis Verlag: Marburg, Germany, 2016; pp. 255-269.

29. Buhl, J. Rebound-Effekte im Steigerungsspiel. Zeit- und Einkommenseffekte in Deutschland. Umweltsoziologie; Nomos Verlagsgesellschaft: Baden-Baden, Germany, 2016.

30. Pfeiffer, C.; Speck, M.; Strassner, C. What Leads to Lunch-How Social Practices Impact (Non-) Sustainable Food Consumption/Eating Habits. Sustainability 2017, 9, 1437. [CrossRef]

31. Visschers, V.; Tobler, C.; Cousin, M.E.; Brunner, T.; Orlow, P.; Siegrist, M. Konsumverhalten und Förderung des umweltverträglichen Konsums. Bericht im Auftrag des Bundesamtes für Umwelt BAFU; ETH Zürich, C.B., Ed.; Consumer Behavior, ETH Zürich: Zürich, Switzerland, 2010. 
32. Herforth, A.; Ahmed, S. The food environment, its effects on dietary consumption, and potential for measurement within agriculture-nutrition interventions. Food Secur. 2015, 7, 505-520. [CrossRef]

33. Hughner, R.S.; McDonagh, P.; Prothero, A.; Shultz, C.J.; Stanton, J. Who are organic food consumers? A compilation and review of why people purchase organic food. J. Consum. Behav. 2007, 6, 1-17. [CrossRef]

34. Lorenz, B.; Langen, N. Determinants of how individuals choose, eat and waste: Providing common ground to enhance sustainable food consumption out-of-home. J. Consum. Stud. 2018, 42, 35-75. [CrossRef]

35. Gazan, R.; Brouzes, C.M.; Vieux, F.; Maillot, M.; Lluch, A.; Darmon, N. Mathematical Optimization to Explore Tomorrow's Sustainable Diets: A Narrative Review. Am. Soc. Nutr. 2018, 9, 602-616. [CrossRef]

36. Müller, C.; Stucki, M.; Zehnder, P.; Ebker, J.; Wohlleben, M.; Baumer, B. The Menu Sustainability Index. Assessment of the environmental and health impact of foods offered in commercial catering. Ernährungsumschau 2015, 63, 198-205.

37. Lukas, M.; Scheiper, M.L.; Ansorge, J.; Rohn, H.; Liedtke, C.; Teitscheid, P. Der Nutritional Footprint-Ein Instrument zur Bewertung von Gesundheits- und Umweltauswirkungen der Ernährung. Ernährungsumschau 2014, 61, 164-170.

38. Meier, T.; Gärtner, C.; Christen, O. Bilanzierungsmethode susDISH. Nachhaltigkeit in der Gastronomie. Gesundheits- und Umweltaspekte in der Rezepturplanung gleichermaßen berücksichtigen. Available online: www.nutrition-impacts.org/media/susDISH.pdf (accessed on 21 December 2019).

39. Speck, M.; Rohn, H.; Engelmann, T.; Schweißinger, J.; Neundorf, D.; Teitscheid, P.; Langen, N.; Bienge, K.; unter Mitarbeit von, G.C.; Friedrich, S.; et al. Entwicklung von integrierten Methoden zur Messung und Bewertung von Speisenangeboten in den Dimensionen Ökologie, Soziales, Ökonomie und Gesundheit. Arbeitspapier Nr. 2. Available online: https://www.nahgast.de/wp-content/uploads/2017/09/NAHGAST_AP ap2_Bewertungsmaster.pdf (accessed on 21 December 2019).

40. Eaternity. Unsere Zukunft Mit Nachhaltiger Ernährung Schon Heute! Available online: https://eaternity.org (accessed on 21 December 2019).

41. FiBL. SMART-Nachhaltigkeitsbewertung im Agrar- und Lebensmittelsektor. Available online: https: //www.fibl.org/de/themen/smart.html (accessed on 21 December 2019).

42. FiBL. Umsetzungskampagne "Klimaschutz in hessischen Großküchen". Available online: https://www.fibl. org/de/projektdatenbank/projektitem/project/1442//190/1370.html (accessed on 21 December 2019).

43. Schmidt-Bleek, F. MAIA: Einführung in die Material-Intensitäts-Analyse nach dem MIPS-Konzept; Birkhäuser: Basel, Switzerland, 1998.

44. Liedtke, C.; Bienge, K.; Wiesen, K.; Teubler, J.; Greiff, K.; Lettenmeier, M.; Rohn, H. Resource Use in the Production and Consumption System-The MIPS Approach. Resources 2014, 3, 544-574. [CrossRef]

45. IPCC. Klimaänderungen 2007 Synthesebericht; IPCC-Koordinierungsstelle: Berlin, Germany, 2008.

46. Rockström, J.; Steffen, W.; Noone, K.; Persson, Å.; Chapin, F.S.; Lambin, E.F.; Lenton, T.M.; Scheffer, M.; Folke, C.; Schellnhuber, H.J.; et al. A safe operating space for humanity. Nature 2009, 461, 472-475. [CrossRef]

47. Steffen, W.; Richardson, K.; Rockström, J.; Cornell, S.E.; Fetzer, I.; Bennett, E.M.; Biggs, R.; Carpenter, S.R.; De Vries, W.; De Wit, C.A.; et al. Planetary boundaries: Guiding human development on a changing planet. Science 2015, 347, 736-746. [CrossRef] [PubMed]

48. Deutsche Gesellschaft für Ernährung; Österreichische Gesellschaft für Ernährung; Schweizerische Gesellschaft für Ernährungsforschung. Referenzwerte für die Nährstoffzufuhr, 4th ed.; Neuer Umschau Buchverlag: Neustadt an der Weinstraße, Germany, 2010.

(C) 2020 by the authors. Licensee MDPI, Basel, Switzerland. This article is an open access article distributed under the terms and conditions of the Creative Commons Attribution (CC BY) license (http://creativecommons.org/licenses/by/4.0/). 